УДК 641.514.3:635.62

(СВ.С. Пуць, к.т.н., А.М. Данилюк

Луцький національний технічний університет

О.В. Маркова, к.т.н.

Національний університет водного господарства та

природокористування

\title{
АНАЛІЗ МЕХАНІЧНИХ ЗАСОБІВ ДЛЯ ВИДАЛЕННЯ ШКІРКИ 3 ПЛОДІВ ГАРБУЗА
}

У статті викладено результати аналізу відомих засобів для очищення шкірки з плодів гарбуза. Розглянуто конструкиії механічних засобів для видалення шкірки з гарбуза, виявлено їхні недоліки.

\section{ГАРБУЗ, ОЧИЩЕННЯ ШКІРКИ, ПЕРВИННА ПЕРЕРОБКА, ЗАСОБИ, МАШИНА}

Постановка проблеми. Підвищений інтерес до такої культури як гарбуз на Рівненщині, яка у 2013 році була постачальником насіння гарбуза для австрійських переробних підприємств, вимагає проведення наукових досліджень, спрямованих на розробку нових напрямків використання гарбуза в Україні.

У Рівненській області на даний час відроджують виробництво гарбуза. У 2019 році компанія ТОВ «Фаворит-Агро» високотехнологічне сільськогосподарське підприємство-виробник, яке було створено в 2005 році в м. Корець Рівненської області, планує засіяти тисячі гектар даною культурою після багаторічної перерви. Успішний розвиток даного напрямку сільськогосподарського виробництва можливий не лише за умови організації збуту продукції, а й за умови розвитку переробного виробництва в господарствах, які займається вирощуванням даної культури.

На даний час виробник зорієнтований на вирощування голонасіннєвого гарбуза. При запровадженні вирощування даного сорту, плоди подрібнюються та заробляються у грунт. Виробник вирішує лише задачу максимального видалення насіння 3 мінімальним його пошкодженням.

У сучасному суспільстві є значний попит на високоякісні харчові продукти, які збагачені харчовими волокнами, що сприяє покращенню фізіологічних процесів в організмі людини. Одним із 
перспективних напрямків є застосування гарбуза для виготовлення «здорових» продуктів.

Висока цінність гарбуза полягає в попередженні сердечносудинних і онкологічних захворювань, ожиріння, тощо [1]. Плоди гарбуза багаті цукром, вітамінами В1, В2, С, каротиноїдами, які мають антиоксидантні властивості. Пектинові речовини, що містяться в плодах гарбуза, знижують рівень холестерину. Враховуючі вище зазначене, гарбуз можна віднести до високофункціональних продуктів харчування. Очищена м'якоть гарбуза може широко використовуватись для отримання дитячого харчування, повидла, цукатів, каш, а шкірка - для отримання пектину. Крім того плоди гарбуза є цінною добавкою до кормів тварин.

Враховуючі вище викладене, можна стверджувати, що розробка технологій та технічних засобів для запровадження багатоцільової переробки гарбузів на продовольчі та кормові цілі є актуальною задачею, вирішення якої буде сприяти багатовекторному розвитку аграрних та переробних підприємств.

Аналіз останніх досліджень і публікацій. Питанням первинної переробки гарбуза присвячено роботи I.С. Сгорова [2], П.М. Овчарова [3], М.Н. Шапрова, Д.В. Сьоміна [4, 5] та інших вчених.

I.C. Єгоров глибоко проаналізував роботу великих комплексів з переробки гарбуза та розкрив технологічні принципи їхнього функціонування. Автор, базуючись на аналізі технологій переробки бахчевих, доводить перспективність та економічну доцільність застосування великих технологічних переробних комплексів у господарствах. Але автор не приділяє уваги питанням удосконалення технологічних процесів i технічних засобів для переробки гарбуза.

П.М. Овчаров запропонував технологічний процес переробки гарбуза, що базується на використанні щіткового апарату, обгрунтував його кінематичні та геометричні параметри. Автором доведено доцільність застосування даного апарату для видалення насіння та можливість подальшого використання плодів у харчовій промисловості.

Автори Шапров М.Н., Сьомін Д.В. дослідили стан галузі переробки гарбуза та спрямували свою роботу на вирішення питання заміни ручної праці засобами механізації 3 метою отримання насіння та очищеної м'якоті для подальшої її переробки. Авторами сформовано технологічні потоки для лінії 3 первинної переробки гарбуза. У ході розробки обладнання авторами 
враховано розміри та індекс форми плоду. Виділено основні фактори, які обумовлюють складність вибору раціональної технології та машин для переробки плодів гарбуза. До яких віднесено: багатоваріантність можливих технічних і технологічних рішень, а також недостатність інформації про взаємодію технічних засобів [5].

Дослідниками також обгрунтовано теоретичні залежності для визначення силових параметрів різання м'якоті гарбуза після його очищення. Теоретичні залежності отримано з урахуванням фізико-механічних властивостей м'якоті та параметрів робочого органу.

У ході аналізу чинних досліджень встановлено наступне:

- переробка м'якоті гарбуза потребує розробки нових ефективних механічних засобів, зокрема для очищення плодів від шкірки;

- відомі устаткування для очищення плодів гарбуза від шкірки мають суттєві недоліки, а саме: складність конструкцій, зняття м'якоті разом із шкіркою, низька якість очищених плодів, обмеженість використання.

Мета дослідження. Проаналізувати механічні засоби для очищення шкірки гарбуза під час його первинної переробки та окреслити напрямки їхнього удосконалення.

Результати дослідження. Первинна переробка гарбуза складається 3 наступних технологічних операцій: очищення плодів від шкірки, розрізання навпіл, відділення насіння. Під час очищення шкірки, як вже було зазначено вище, спостерігається висока ступінь травмування м'якоті, що впливає на якість кінцевої продукції.

Аналіз відомих засобів для очищення шкірки 3 плодів гарбуза виявив, що основними способами видалення шкірки є:

- механічний,

- фізичний,

- хімічний,

- комбінований.

Механічний спосіб здійснюється за рахунок тертя шкірки по шорсткій поверхні робочого органу, до якого плід повинен щільно притискатись. Якість процесу очищення залежить від величини поверхні контакту робочої поверхні та плоду, сили притискання та виду відносного руху поверхні та гарбуза.

Недоліки механічного методу, які найчастіше проявляються - пошкодження м'якоті та неповне очищення, що пояснюється недосконалістю конструкцій механічних засобів. 
Фізичний спосіб очищення здійснюється за рахунок впливу пари, яка подається під значним тиском і розпарює поверхневий шар плоду. Розпарений шар далі очищується та змивається у миєчно-очищуючих машинах. Крім впливу пари застосовують обпалювання шкірки у термоагрегатах за температури вище $800^{\circ} \mathrm{C}$, яка далі очищується щітками в миєчно-очищуючих машинах.

Даний спосіб є енергозатратним і не забезпечує високої якості очищення та не отримав широкого застосування в промисловості.

Хімічний спосіб очищення базується на застосуванні лугів. Після обробки теплим лужним розчином шкірку очищують роликами, а плоди промивають від лужного розчину.

Комбінований спосіб передбачає обробку парою та лугами.

Хімічний та комбінований способи потребують також значних витрат води для обмивання плоду після обробки лугами. Крім того, для здійснення даних способів потрібні значні витрати енергії для нагрівання води та пари.

3 урахуванням цього, найбільш перспективним $\epsilon$ механічний спосіб очищення шкірки 3 плодів гарбуза. Проаналізуємо чинні механічні засоби для здійснення даного способу.

Відомим є устаткування [6] для очищення плодів бахчевих культур. Авторами вирішується задача підвищення якості очищення плодів, зменшення енерговитрат та, як наслідок, собівартості продукції. Устаткування для очищення плодів баштанних культур містить раму, бункер, приводний барабан 3 щітками на внутрішній поверхні i встановлену в порожнині барабана додаткову щітку. За рахунок того, що додатковій щітці надано зворотно-поступальне вертикальне переміщення, досягається висока якість очищення шкірки (рис.1).

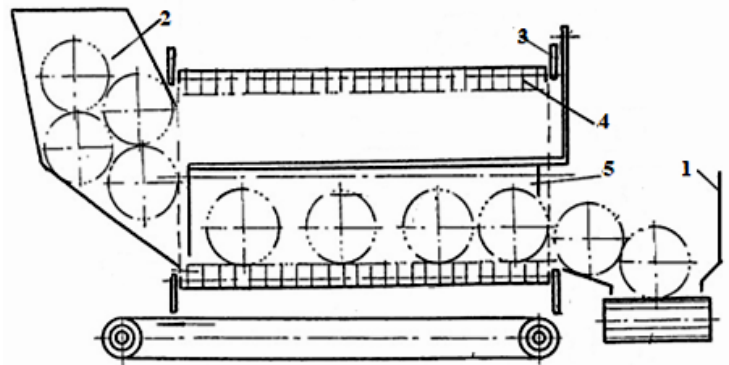

Рис. 1 - Схема устаткування для очищення плодів бахчевих культур [6]: 1-рама, 2-бункер, 3-барабан, 4- щітки, 5-додаткова щітка 
Слід відмітити, що конструктивним недоліком даної конструкції є послідовне встановлення щіткових барабанів. Крім того кінці щіток не можуть забезпечити високу ефективність впливу на шкірку плодів різної форми та розміру.

На усунення даних недоліків спрямоване технічне рішення, запропоноване авторами В.Г. Абезіним, В.В. Карпуніним та ін. [7]. Запропонований авторами пристрій (рис. 2) містить щіткові барабани, утворені порожнистим вальцем 3 ведучою та веденою цапфами на кінцях. На поверхні вальця з рівним кроком розміщені радіально орієнтовані гофровані лопаті, між якими розміщені частини багатожильного металевого каната. Гілки кожної частини каната покладені в гофри і з лопатями з'єднані за допомогою пари планок і кріпильних елементів. Багатожильний канат в устаткуванні входить у шкірку плоду, при цьому знімається тверда частина, а плоди набувають обертового руху й барабани знімають 3 плодів шар шкірки, що залишився.
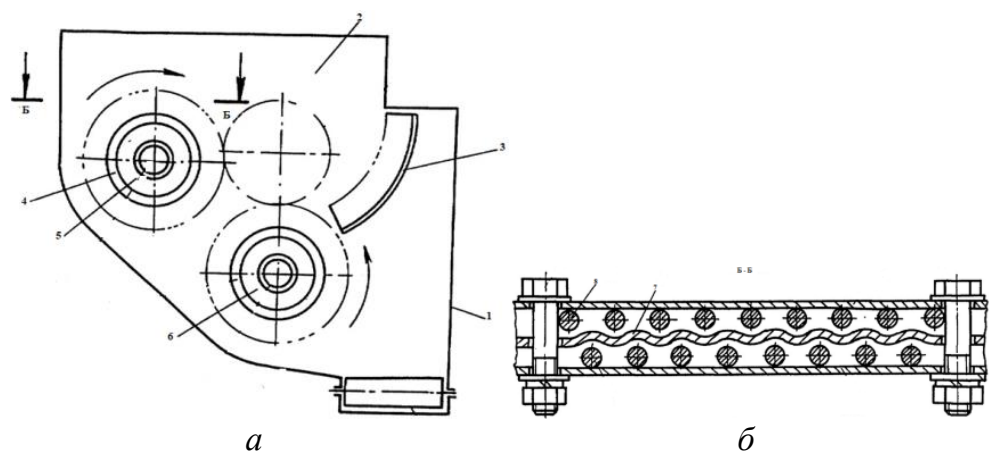

Рис. 2 - Схема устаткування для очищення плодів бахчевих культур [7]: $a$ - вертикальний переріз устаткування, $\sigma$ - вид Б-Б: 1 - рама, 2 - бункер, 3 - підпірна щітка, 4 - порожнистий валок, 5,6 - барабани, 7,8 - канат

На наш погляд, дане технічне рішення забезпечує очищення плодів різного розміру за рахунок того, що плоди переміщуються по похилій площині під час впливу на них барабанів, а також за рахунок регулювання підпірної щітки. В той же час застосування багатожильного канату $€$ недоліком даного пристрою, що пояснюється його швидким зношуванням та складністю процесу заміни. 
М.Н. Шапров, Д.В. Сѐмин, А.В. Кузнецов [8] для очищення гарбуза від шкірки запропонували застосовувати пристрій, який містить фрезерний барабан (рис. 3). Розроблена авторами машина забезпечує переробку попередньо розрізаних кусків гарбуза 11 , які по лотку 2 подають у простір між опорним валком 3 та голчастим валком 4, які переміщують їх у напрямку фрезерного барабану 5 , який зрізує шкірку.

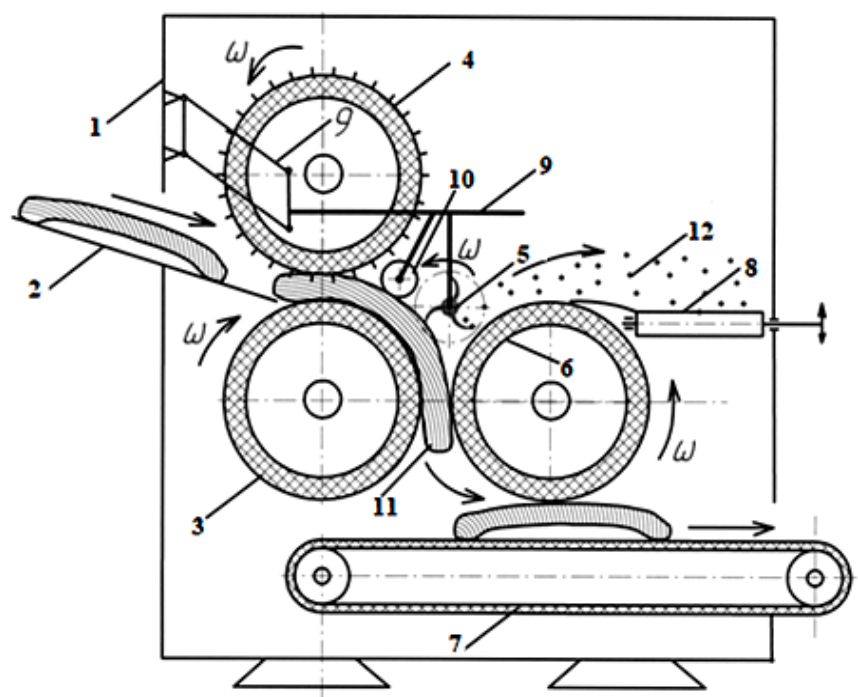

Рис. 3 - Машина для очищення бахчевих культур [8]: 1 - рама, 2 - лоток, 3 - опорний валок, 4 - валок голчастий, 5 - фрезерний барабан, 6 - притискний валок, 7 - транспортер очищених дольок, 8 - транспортер шкірки, 9 - тримач, 10 - копіюючи колесо, 11 - плоди, 12 - шкірка

Запропонована конструкція машини не вирішує задачі виключення ручної праці з процесу очищення шкірки гарбуза. Шматочки потрібно закладати вручну у машину.

На Українському ринку з'явились машини для очищення шкірки з гарбуза китайського виробництва ZН-XP1 (рис. 4). 


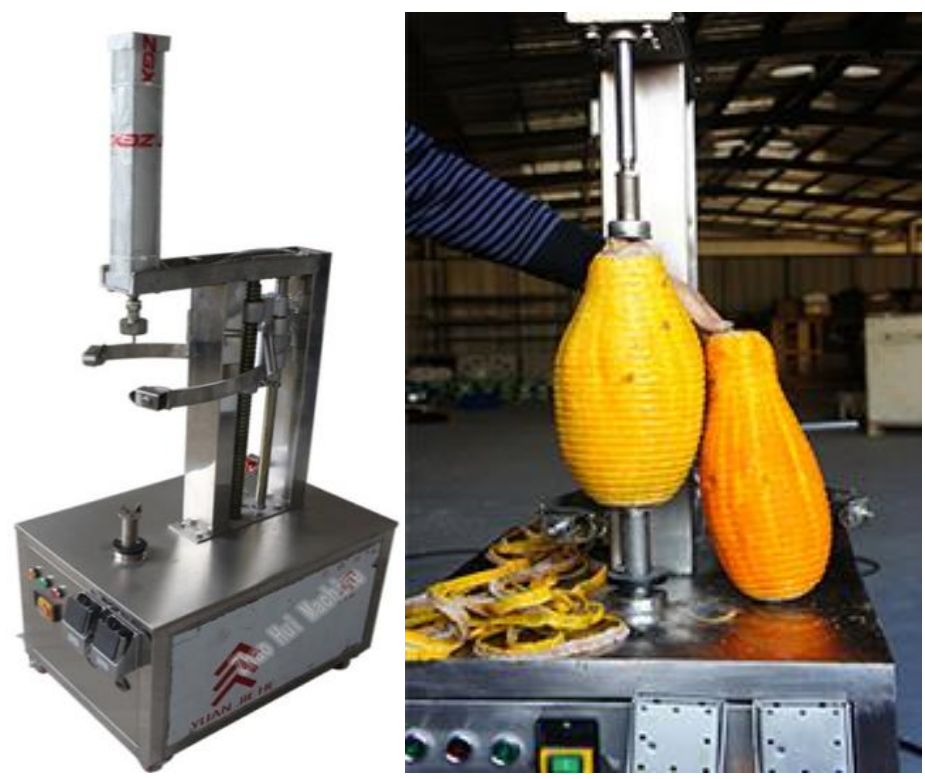

Рис. 4 - Машина для очищення гарбуза (Китай)

Дана машина має продуктивність 50 шт/год. Встановлення та зняття плоду здійснюється вручну. Машина вузькофункціональна, призначена для очищення гарбуза певних сортів. Очищення проводиться обертовими ножами.

За таким же принципом створено машину Titan FXP-99 та машину для очищення гарбузів (Росія) (рис. 5). Дані машини призначено для очищення плодів видовженої форми. Продуктивність машин 500 шт./год. (Titan FXP-99) та 50 шт./год. Завантаження та зняття плоду проводять вручну, що збільшує собівартість готової продукції. 


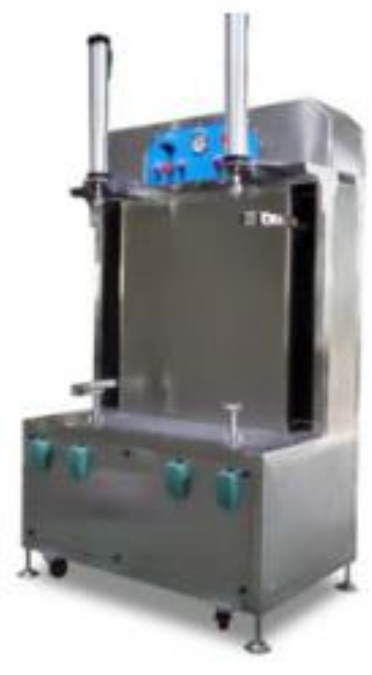

$a$

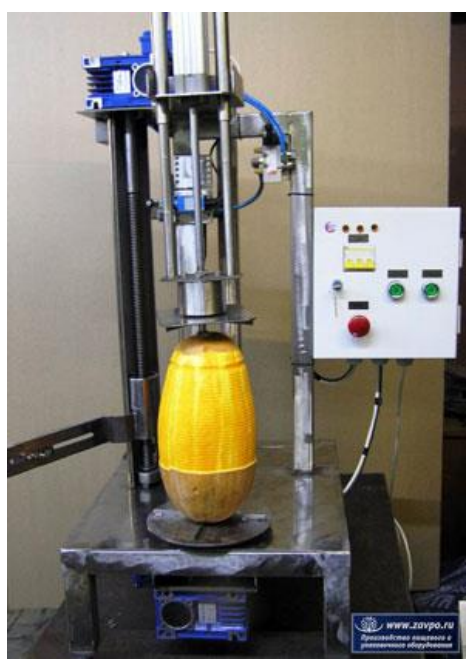

$\sigma$

Рис. 5 - Машина для очищення гарбуза (Росія): $a$ - Titan FXP-99 (Довгопрудний, Росія); $\sigma-$ машина виробництва ООО «Воплощение» (Подільськ, Росія)

В результаті аналізу наявних конструктивних рішень, встановлено, що практично всі пристрої і машини так і залишилися лише експериментальними розробками. Впровадження в промислове виробництво вони не отримали. Машини, які випускаються промисловістю потребують використання ручної праці та не можуть бути включеними до складу потокових ліній сучасних автоматизованих виробництв.

Висновки. Для отримання харчових продуктів із гарбуза потрібно у видаляти шкірку, яка надає готовому продукту гіркуватого присмаку. Існуючі технології звільнення плодів від шкірки, в основному, базуються на використанні ручної праці, що веде до зростання собівартості продукції, зменшення продуктивності виконання процесу очищення. У зв'язку з цим задача розробки машини для очищення плодів гарбуза від шкірки залишається актуальною та потребує вирішення.

Основними задачами, які потрібно вирішити в ході розробки механічних засобів для очищення шкірки 3 плодів гарбуза:

- повне виключення ручної праці; 
- унеможливлювання пошкодження м'якоті плоду;

- забезпечення універсальності обробки (обробка плодів будь якої форми);

- простота конструкції;

- низька енергозатратність процесу обробки.

\section{Література}

1. Colagar A.H. Review of pumpkin anticancer effects/A.H. Colagar, O.A. Souraki// Quran. Med. - 2012. - V.1(4). P. 77-88.

2. Егоров И.С. Обоснование и исследование процесса подбора плодов арбузов накатыванием бесконечными рабочими поверхностями: автореф. дис. ... канд. техн. наук: 05.20.01 / И.С. Егоров. - М., 1970. - 21 с.

3. Овчаров П.М. Разработка технологического процесса выделения семян тыквенных культур и обоснование параметров его отделяющего аппарата: автореф. дис. ... канд. техн. наук: 05.20.01 / П.М. Овчаров. - Волгоград, 1984.-21 с.

4. Шапров М.Н.. Определение основных кинематических параметров машины для резания очищеной мякоти плодов бахчевых/ М.Н. Шапров, Д.В. Семин, М.А. Садовников// Известия Нижневолжского агр. ун-та. № 2(30). - 2013. С.1-5.

5. Шапров М.Н. Формирование технологического потока при переработке плодов бахчевых культур / М.Н. Шапров, Д.В. Семин, М.А. Садовников, А.В. Кузнецов// Известия Нижневолжского агр. ун-та. № 1 (17). - 2010. С.140-146.

6. Патент. 2225143. Россия. МПК $^{7}$ А23N7/00. Устройство для очистки плодов бахчевых культур. Петров Н.Ю., Салдаев А.М., Жаринов Е.М., Бородычев В.В.; заявитель и патентообладатель Волгоградская госуд. сельскохозяйственная академия № 2002121822; заявл. 01.11.2003, опубл. 20.05. 2004.

7. Патент 2188568. Россия. МПК-8 А23N7/00 Устройство для очистки плодов бахчевых культур. Абезин В.Г., Карпунин В.В., Цепляев А.Н., Шапров М.Н., Салдаев А.М.; заявитель и патентообладатель Поволжский НИИ эколого-мелиоративных технологий - № 2287307; заявл. 01.12.2001, опубл. 10.09.2002.

8. Патент 2389417. Россия. МПК А23 N15/00. Машина для удаления коры с плодов бахчевых культур. Шапиров М.Н., Семин Д.В., Кузнецов А.В.; заявитель и патентообладатель Волгоградская госуд. сельскохозяйственная академия № 2008152519/13; заявл. 29.12.09, опубл. 20.05.10. Бюл. №14. 